\title{
Penerapan Antrian dan Pemesanan Online di Aplikasi Pearl Salon And BarberShop Berbasis Mobile
}

\author{
Alfian Rizaldi ${ }^{1)}$, Viktor Handrianus Pranatawijaya ${ }^{2 *)}$, \\ Putu Bagus Adidyana Anugrah Putra ${ }^{3)}$ \\ 122)3) Teknik Informatika, Fakultas Teknik, Universitas Palangkaraya \\ Jalan Hendrik Timang, Kota Palangkaraya, Kalimantan Tengah, Indonesia \\ *corresponding author \\ 1) alfian.rizaldi98@gmail.com \\ 2) viktorhp@it.upr.ac.id \\ 3) putubagus@it.upr.ac.id
}

\begin{abstract}
Abstrak
Pearl Salon and Barbershop merupakan penyedia pelayanan dan jasa yang bergerak dalam bidang perawatan tubuh wanita dan pria di kota Palangkaraya. Pearl Salon and Barbershop sendiri berkeinginan untuk meningkatkan jumlah omset dan menjaga loyalitas customer pearl dalam pelayanan dan jasa di bidang perawatan tubuh dengan membuat aplikasi antrian dan pemesanan secara online.

Membangun aplikasi ini menggunakan metodologi pengembangan perangkat lunak metode extreme programming (xp), yang memiliki tahapan, Exploration phase (Fase eksplorasi), Planning phase (Fase Perencanaan), Iteration Phase (Fase Iterasi), Production Phase (Fase Produksi), dan Maintenance Phase (Fase Pemeliharaan). Adapun pada tahap konsep yaitu dengan mendeskripsikan proyek serta analisis sistem yang akan dibuat. Tahap pembuatan aplikasi dan website pada penelitian ini menggunakan Android Studio, Firebase, $X M L$, Java, PHP, Javascript, CSS, dan JSON. Pengujian yang dilakukan terhadap aplikasi dan website ini menggunakan jenis pengujian Black Box, dimana pengujian Black Box berfokus pada persyaratan atau kebutuhan fungsional perangkat lunak yang dibuat.

Dengan dibangunnya Aplikasi Pearl Salon and Barbershop ini dapat menghasilkan sistem antrian dan pemesan yang memudahkan customer salon dan barbershop, dan mewujudkan pelayanan yang optimal, sehingga owner dapat meningkat kan kepercayaan dan pendapatan dari customer salon dan barbershop itu sendiri.
\end{abstract}

Kata kunci: Antrian, Pemesanan Online, Pearl Salon and Barbershop

\begin{abstract}
Pearl Salon and Barbershop is a provider of services and services engaged in the body care of women and men in the city of Palangkaraya. Pearl Salon and Barbershop itself wants to increase the number of turnover and maintain customer loyalty pearl in the service and services in the field of body care by creating queue applications and ordering online.

Building this application uses extreme programming (xp) method software development methodology, which has stages, Exploration phase, Planning phase, Iteration Phase, Production Phase, and Maintenance Phase. At the concept stage, namely by describing the project and analysis of the system to be made. The application and website creation phase of this study used Android Studio, Firebase, XML, Java, PHP, Javascript, CSS, and JSON. The tests performed on these applications and websites use a type of Black Box testing, where the Black Box testing focuses on the requirements or functional needs of the software created.

With the construction of Pearl Salon and Barbershop application can produce a system of queues and bookers that facilitate customers salon and barbershop, and realize optimal service, so that the owner can increase the trust and income of the customer salon and barbershop itself
\end{abstract}




\section{Keywords: Queue, Online Ordering, Pearl Salon and Barbershop}

\section{PENDAHULUAN}

\subsection{Latar Belakang}

Pearl Salon and Barbershop merupakan penyedia pelayanan dan jasa yang bergerak dalam bidang perawatan tubuh wanita dan pria di kota Palangkaraya. Kegiatan pelayanan, jasa tersebut dilakukan secara offline seperti pelayanan dan jasa perawatan pada umumnya. Didalam sistem pelayanan secara offline di temukan kelemahan yang menjadi masalah owner selama ini yaitu dengan menumpuknya antrian customer ketika ingin melakukan treatment yang mengakibatkan tumpukan antrian yang sangat menggangu sehingga banyak customer yang tidak mau melakukan treatment karena terlalu lama menunggu di karenakan customer tersebut datang langsung ke tempat dan tidak melakukan pemesanan terlebih dahulu via Telepon atau WhatsApp. Dengan menggunakan Telepon atau WhatsApp sering terjadi kendala seperti ketika banyaknya jumlah pemesanan tempat melalui telepon atau apilkasi pihak ketiga sering tidak terhandle dan customer tidak mendapatkan treatment maksimal.

Pearl Salon and Barbershop sendiri berkeinginan untuk meningkatkan jumlah omset dan menjaga loyalitas customer pearl dalam pelayanan dan jasa di bidang perawatan tubuh. Untuk mencapai tujuan tersebut cara yang dilakukan yakni dengan mencari solusi terbaik yang diyakini dapat mengatasi permasalahan-permasalahan di atas. Dengan adanya aplikasi yang dibuat yaitu merancang suatu aplikasi bagi customer agar dapat melakukan pemesanan treatment secara online dan website bagi administrator/front office. Customer dapat melakukan pemesanan treatment tanpa harus datang ke tempat untuk mengantri dan dapat mengatur tanggal treatment sesuai tanggal yang di tentukan customer sendiri.

\section{TINJAUAN PUSTAKA}

Dalam pengembangan penelitian yang berjudul "Penerapan Antrian dan Pemesanan Online di Aplikasi Pearl Salon and Barbershop berbasis Mobile" maka penulis menuangkan beberapa penelitian terdahulu yang pernah diteliti sebagai acuan dalam analisis penelitian ini akan dilakukan analisis sebagai pembanding dengan penelitian yang telah ada sebelumnya. Berdasarkan Rancang Bangun Aplikasi Antrian Poliklinik Berbasis Mobile [1], dan Rancang Bangun Aplikasi Pemesanan Tiket Travel Study Kasus : Kota Palangka Raya [2] di gunakan sebagai dasar penelitian ini dan Rancang Bangun Aplikasi Mobile Pemesanan Makanan dan Minuman pada Cafe [3] sebagai acuan dalam mengembangkan fitur fitur yang akan di buat.

\subsection{Teori Pendukung}

\subsubsection{Antrian}

Sistem antrian adalah himpunan customer, pelayan, dan suatu aturan yang mengatur kedatangan para customer dan pelayanannya [4]. Sistem antrian merupakan " proses kelahiran - kematian " dengan suatu populasi yang terdiri atas para customer yang sedang menunggu pelayanan atau yang sedang dilayani. Kelahiran terjadi jika seorang customer memasuki fasilitas pelayanan, sedangkan kematian terjadi jika customer meninggalkan fasilitas pelayanan. Keadaan sistem adalah jumlah customer dalam suatu fasilitas pelayanan.

Desain sarana pelayanan dapat diklasifikasikan dalam channel dan phase yang akan membentuk suatu struktur antrian yang berbeda-beda. Channel menunjukkan jumlah jalur untuk memasuki sistem pelayanan. Phase berarti jumlah stasiun-stasiun pelayanan, dimana para langganan harus melaluinya sebelum pelayanan dinyatakan lengkap. Single Chanel berarti bahwa hanya ada satu jalur untuk memasuki sistem pelayanan atau ada satu pelayanan. Single phase menunjukkan bahwa hanya ada satu stasiun pelayanan sehingga yang telah menerima pelayanan dapat langsung keluar dari sistem antrian. Contohnya antrian pada penjualan karcis kereta api yang hanya dibuka satu loket [5]. 


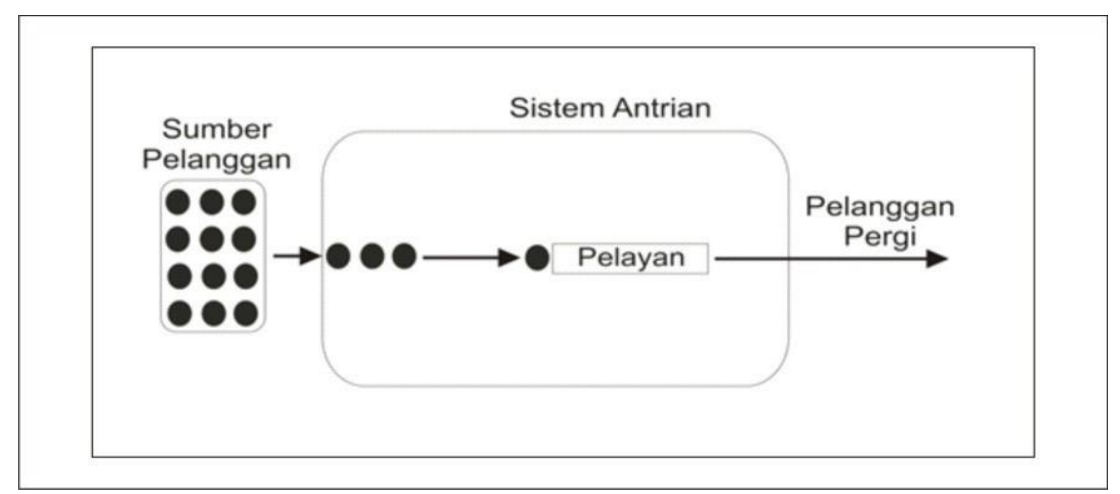

Gambar 1. Sistem antrian single chanel-single phase

\subsubsection{Unified Modeling Language (UML)}

Merancang bisnis proses adalah menemukan suatu cara untuk menyelesaikan masalah, salah satu model untuk merancangnya adalah menggunakan UML [6][7].

Berdasarkan Systems Analysis \& Design With UML Version 2.0; An Object-Oriented Approach 4th Edition [8], UML disebut sebagai tekhnik pendiagraman yang berorientasi objek yang memiliki banyak permodelan sistem pengembangan projek dari analisis ke pendesainan. UML biasanya disajikan dalam bentuk diagram/gambar yang meliputi class beserta atribut dan operasinya, serta hubungan antar class. UML terdiri dari banyak diagram, diantaranya :

\section{a. Use Case Diagram}

Sebuah use case dapat mewakili sistem bisnis berinteraksi dengan lingkungannya. Ini menggambarkan kegiatan yang dilakukan oleh para pengguna sistem. Pemodelan use case sering dianggap sebagai pandangan eksternal atau fungsional bisnis proses, hal itu menunjukkan bagaimana pengguna melihat proses, bukan mekanisme internal dimana proses dan sistem pendukung beroperasi.

b. Activity Diagram

Diagram aktivitas digunakan untuk memodelkan perilaku objek dalam proses bisnis. Dalam banyak hal, diagram aktivitas dapat dipandang sebagai diagram aliran data yang dihubungkan dengan analisis terstruktur.

c. Class Diagram

Sebuah diagram kelas adalah model statis yang menunjukkan kelas dan hubungan antar kelas yang tetap konstan dalam sistem dari waktu ke waktu. Diagram kelas menggambarkan kelas, yang mencakup baik perilaku dan negara, dengan hubungan antar kelas

\subsubsection{Testing Perangkat Lunak}

Berdasarkan Konsep Dasar Rekayasa Perangkat Lunak [9], testing adalah sebuah proses yang dijelaskan sebagai siklus hidup dan merupakan bagian dari proses rekayasa perangkat lunak secara terintegrasi demi memastikan kualitas dari perangkat lunak serta memenuhi kebutuhan teknis yang telah disepakati dari awal.

\section{METODE PENELITIAN}

Adapun metode yang digunakan pada pembuatan program ini adalah extreme programming $(X P)$ [10], di mana Terdapat empat tahapan yang harus dikerjakan pada metode extreme programming dalam "Penerapan Antrian dan Pemesanan Online di Aplikasi Pearl Salon and Barbershop berbasis Mobile", yaitu: 
1. Exploration phase (Fase eksplorasi).

Fase eksplorasi memfokuskan pada pengambilan kebutuhan klien. Pada tahap ini visi produk dan tujuan bisnis aplikasi dirumuskan dan diatur kembali. Hasil dari tahap ini adalah sekumpulan kebutuhan pengguna beserta prototipe yang ditunjukkan untuk tahap berikutnya.

2. Planning phase (Fase Perencanaan).

Fase perencanaan memfokuskan pada pemilihan kebutuhan yang sesuai dengan batasanbatasan yang dimiliki klien dan tim. Kesepakatan fase ini menghasilkan rencana rilis dan rencana iterasi. Rencana rilis adalah melampirkan fitur-fitur yang akan dikembangkan dalam jangka waktu yang telah disepakati. Rencana iterasi menghasilkan sekumpulan tahapantahapan yang akan dilakukan beserta keluaran yang diperoleh untuk setiap tahapan.

3. Iteration Phase (Fase Iterasi).

Fase ini dikenal juga dengan fase pengembangan solusi. Fase iterasi adalah melakuan eksekusi perencanaan iterasi melalui serangkaian aktivitas teknis seperti pembuatan arsitektur, pembuatan kode, dan melakukan unit test untuk setiap modul. Hasil keluaran setiap iterasi dikenal dengan rilis parsial/small release.

4. Production Phase (Fase Produksi).

Fase ini melakukan pengujian terhadap hasil setiap iterasi. Tim akan melakukan pengujian dengan melibatkan klien. Pada tahapan ini dilakukan juga verifikasi dan integrasi terhadap hasil dengan rencana rilis yang ada. Hasil fase ini adalah sebuah solusi yang sudah dites baik oleh tim dan klien.

5. Maintenance Phase (Fase Pemeliharaan).

Fase ini memfokuskan pada layanan didukung setelah software tersebut dikembangkan. Fase ini melakukan perbaikan kesalahan pada solusi dan penyesuaian kecil pada solusi. Pada fase ini dimungkinkan pula terjadi kesepakatan untuk pengembangan sistem pada rilis selanjutnya.

\section{PEMBAHASAN}

Tahap ini dilakukan berdasarkan Extreme Programming $(X P)$. Pada bagian perencanaan sistem ini dijelaskan dua tahap awal dari tahap pengembangan Extreme Programming tersebut, yaitu Exploration phase (Fase eksplorasi), Planning phase (Fase Perencanaan), Iteration Phase (Fase Iterasi), dan Production phase (Fase Produksi) yang didalamnya akan dimuat tentang bagaimana konsep, perencanaan, analisa serta perancangan apa saja yang dibutuhkan oleh sistem yang akan dibangun [11].

\subsection{Exploration phase (Fase explorasi)}

\subsubsection{Implementasi sistem}

Dalam Berdasarkan hasil observasi dan wawancara yang telah dilakukan, maka dapat diidentifikasikan permasalahan yang saat ini dihadapi adalah sebagai berikut:

1. Tidak efisiennya proses antrian pelanggan yang mengakibatkan menumpuknya pelanggan.

2. Sering terjadinya penumpukan pelanggan yang mengakibatkan pelanggan tidak betah menunggu lama.

3. Proses pemesanan masih menggunakan cara manual dan menggunakan aplikasi pihak ketiga.

\subsubsection{Strategi pemecahan masalah}

Untuk mengatasi suatu permasalahan dibutuhkan strategi yang matang. Oleh karena itu dibutuhkan tahapan analisa terhadap aplikasi dan website yang dibentuk. Tahapan analisa terhadap suatu sistem dilakukan sebelum tahapan perancangan dibuat. 


\subsection{Planning phase (Fase perencanaan)}

\subsubsection{Analisa sistem}

Analisa sistem dilakukan untuk mengetahui, mengidentifikasi dan mengevaluasi permasalahan-permasalahan, hambatan-hambatan yang terjadi, dan kebutuhan sistem sehingga dapat diusulkan perbaikannya. Berdasarkan permasalahan tersebut maka dapat didefinisikan kebutuhan fungsional dan non fungsional dari aplikasi pearl salon and barbershop.

\subsection{Iteration phase (Fase Iterasi)}

Fase ini merupakan fase perancangan aplikasi yaitu berupa perancangan proses dan sistem, aplikasi dan website Administrator ini menggunakan pemodelan UML.

\subsubsection{Use Case Diagram}

Use case diagram menggambarkan fungsionalitas proses yang di harapkan terjadi dari sebuah sistem. Use case merepresentasikan sebuah interaksi antara aktor dengan sistem [12]. Diagram use case digunakan untuk menggambarkan user yang menggunakan sistem dan perilaku user terhadap aplikasi [13].

a. Use Case Diagram Aktor Customer dan Aktor Front Office
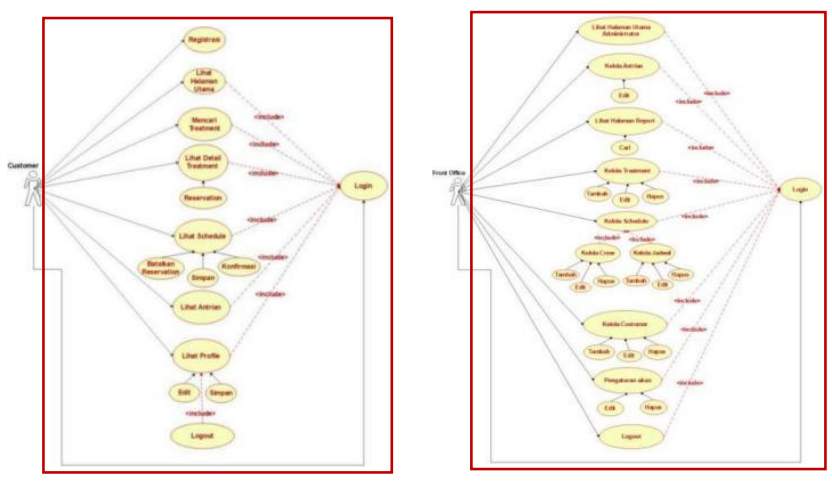

Gambar 2. Use case diagram customer dan front office

\subsubsection{Activity Diagram}

Activity Diagram atau diagram aktivitas berfungsi untuk memodelkan alur kerja (workflow) sebuah proses dan aktivitas dalam suatu proses Activity Diagram juga digunakan untuk mendefinisikan atau mengelompokan aluran tampilan dari sistem[14].

a. Activity Diagram Aktor Customer

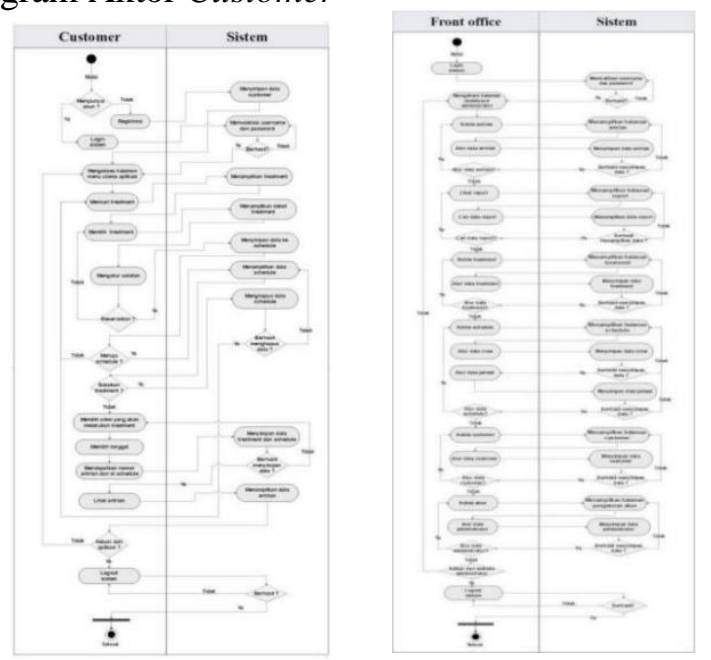

Gambar 3. Activity diagram customer dan front office 


\subsubsection{Class Diagram}

Diagram kelas menggambarkan komponen-komponen pembentuk sistem yang berupa kelas atau interface, dan hubungan antar komponen tersebut. [15]

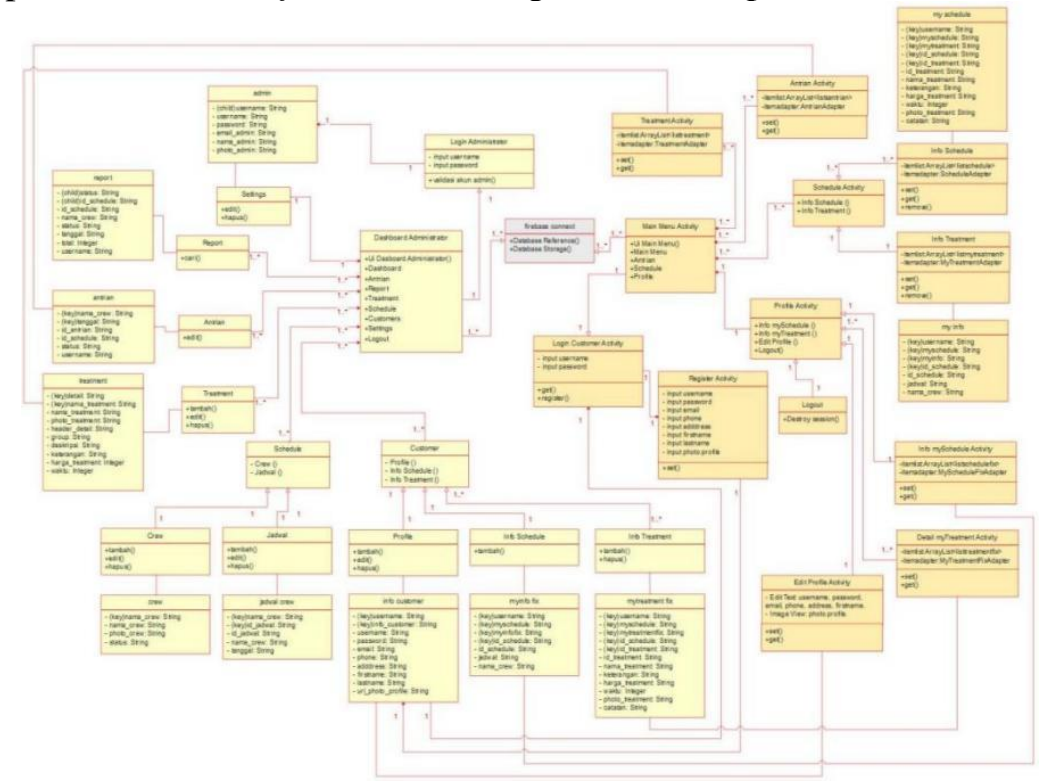

Gambar 4. Class diagram sistem

\subsection{Production phase (Fase produksi)}

Pada tahap Production Phase (Fase Produksi), terdapat implementasi dan pengujian terhadap sistem baru. Tahap implementasi dan pengujian sistem dilakukan setelah tahap analisa dan perancangan selesai dilakukan.

\subsubsection{Implementasi sistem}

Implementasi sistem merupakan penyatuan unit program kemudian uji secara keseluruhan.Unit program atau program individual diintegrasikan dan diuji sebagai sistem yang lengkap untuk menjamin bahwa persyaratan sistem telah dipenuhi.Setelah pengujian sistem, perangkat lunak dikirim ke User.

a. Implementasi Aplikasi Android

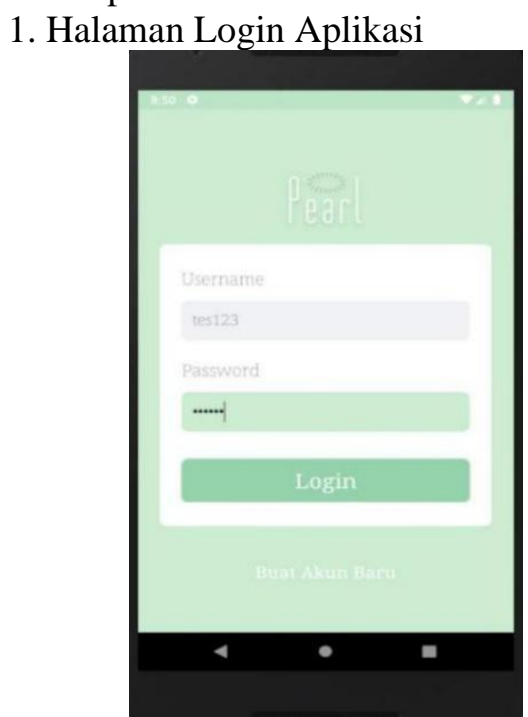

Gambar 5. Halaman login aplikasi 


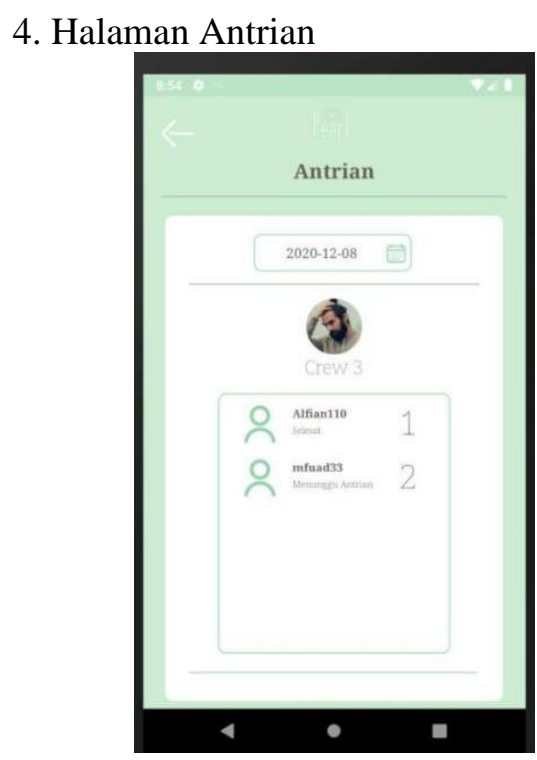

Gambar 6. Halaman antrian

b. Implementasi Website Administrator

1. Halaman Login Website Administrator

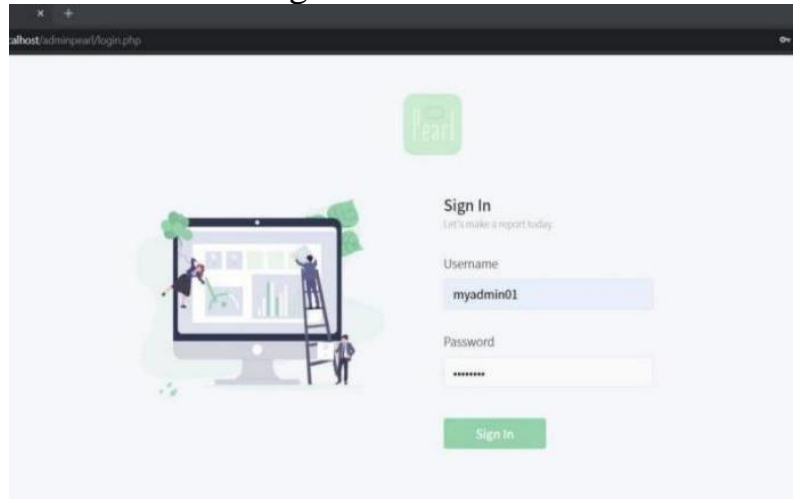

Gambar 7. Halaman login website administrator

2. Halaman Antrian Website Administrator

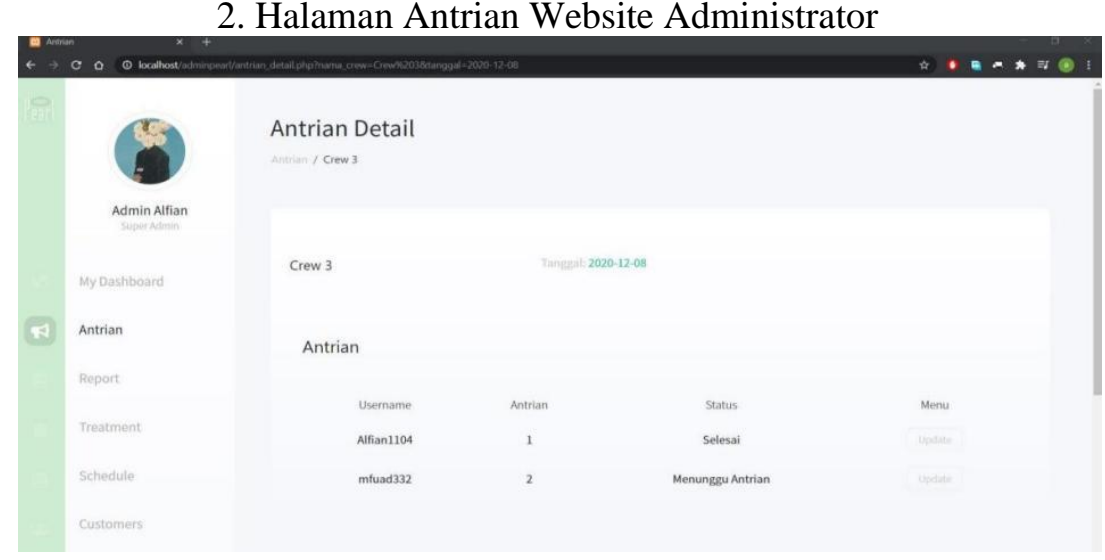

Gambar 8. Halaman antrian website administrator 


\subsubsection{Pengujian sistem}

Pengujian merupakan elemen kunci dari XP. Pengujian dilakukan untuk dapat memastikan apakah aplikasi dapat berjalan dengan baik dan benar sesuai dengan kebutuhan dan tujuan yang diharapkan [16]. Setelah melakukan implementasi, dilakukan pengujian terhadap sistem dengan tujuan untuk melihat semua kesalahan dan kekurangan yang ada pada sistem [17].

Tabel 1. Pengujian sistem aplikasi

\begin{tabular}{|c|c|c|c|c|}
\hline No & Pengguna & Activity & Proses & Hasil \\
\hline 1 & Customer & Login & $\begin{array}{l}\text { Login salah username (tidak dapat masuk). } \\
\text { Login salah password (tidak dapat masuk). } \\
\text { Login salah username \& password (tidak dapat } \\
\text { masuk). } \\
\text { Login Username dan Password Benar (dapat masuk } \\
\text { ). }\end{array}$ & Ok \\
\hline 2 & Customer & Register & $\begin{array}{l}\text { Memasukkan input dengan data-data pribadi dan } \\
\text { foto profile. } \\
\text { Menyimpan data pribadi dan foto profile. }\end{array}$ & Ok \\
\hline 3 & Customer & Main Menu & $\begin{array}{l}\text { Memasukkan input pencarian dengan mengisi nama } \\
\text { treatment yang ingin di cari. } \\
\text { Memilih menu treatment dan paket yang tersedia } \\
\text { (Sistem masuk ke dalam list data treatment } \\
\text { berdasarkan menu yang dipilih). }\end{array}$ & $\mathrm{Ok}$ \\
\hline 4 & Customer & Searching & $\begin{array}{l}\text { Menampilkan data berdasarkan input pencarian } \\
\text { yang telah disi. }\end{array}$ & $\mathrm{Ok}$ \\
\hline 5 & Customer & Sorting & $\begin{array}{l}\text { Menampilkan data berdasarkan data termurah. } \\
\text { Menampilkan data berdasarkan data termahal. }\end{array}$ & Ok \\
\hline
\end{tabular}

\section{KESIMPULAN}

Dalam pengembangan penelitian yang berjudul "Penerapan Antrian dan Pemesanan Online di Aplikasi Pearl Salon and Barbershop berbasis Mobile", maka dapat disimpulkan dalam merancang dan membangun aplikasi ini menggunakan metodologi pengembangan perangkat lunak metode extreme programming $(x p)$ [18][19], yang memiliki tahapan, Exploration phase (Fase eksplorasi), Planning phase (Fase Perencanaan), Iteration Phase (Fase Iterasi), Production Phase (Fase Produksi), dan Maintenance Phase (Fase Pemeliharaan).

Penerapan antrian dan pemesanan online di aplikasi Pearl Salon and Barbershop menggunakan sistem antrian dengan desain pelayanan Single Chanel-Single Phase, dan disiplin pelayanan First come first served (FCFS) atau first in first out (FIFO) dimana yang akan dilayani ialah customer yang melakukan pemesanan terlebih dahulu, sehingga customer dapat menyesuaikan waktu yang diingin ketika melakukan pemesanan treatment dan antrian menjadi lebih teratur.

Pengujian yang dilakukan terhadap aplikasi dan website ini menggunakan jenis pengujian Black Box, dimana pengujian BlackBox berfokus pada persyaratan atau kebutuhan fungsional perangkat lunak yang dibuat. Pengujian aplikasi dan website menggunakan data uji berupa sebuah data masukan dari customer, sehingga dari pengujian tersebut dapat dilihat respon sistem ketika diinputkan data yang salah dan data yang benar.

\section{DAFTAR PUSTAKA}

[1] A. Z. Rizal, A. A. Suprianto, Rancang Bangun Aplikasi Antrian Poliklinik Berbasis Mobile. Jurnal Teknologi Informasi dan Ilmu Komputer 5(3), 361-370, 2018.

[2] Febrianto, Yoan. Rancang Bangun Aplikasi Pemesanan Tiket Travel, Study Kasus : Kota Palangka Raya. Jurusan Teknik Informatika, Universitas Palangka Raya. Palangka Raya, 2019. 
[3] Hidayat, Denny. Rancang Bangun Aplikasi Mobile Pemesanan Makanan dan Minuman pada Cafe. Jurusan Teknik Informatika, Universitas Palangka Raya. Palangka Raya, 2020.

[4] Anaviroh. Model Antrian Satu Server Dengan Pola Kedatangan Berkelompok (Batch Arrival).Fakultas Matematiika dan Pengetahuan Alam, Universitas Negeri Yogya, 2012. [Online]. (http://eprints.uny.ac.id/237/1/Anaviroh-07305144027.pdf), diakses pada 13 Maret 2020.

[5] Ary. Maxsi, Pendekatan Teori Antrian Single Chanel Single Phase Pada Pelayanan Administrasi. Jurnal Teknologi Informasi 3(1), 21-27, 2018.

[6] V. H. Pranatawijaya, Penerapan Google Maps API Pada Sistem Informasi Geografis (SIG) Tempat Wisata dan Rekreasi Kota Palangkaraya Berbasis Web. Jurnal Teknologi Informasi 8 (1), 53-58,2014.

[7] V. H. Pranatawijaya Rancangan Aplikasi Bergerak Penjadwalan Distribusi Sembako pada UD. Kuning Mas Palangka Raya. Jurnal Teknologi Informasi 13 (2), 60-69, 2019.

[8] Dennis, Alan. Systems Analysis \& Design With UML Version 2.0; An Object- Oriented Approach 4th Edition. John Wiley \& Sons, Inc.Edition, McGraw- Hill Book, Co,2012.

[9] Rizky, Soetam. Konsep Dasar Rekayasa Perangkat Lunak. Jakarta: Prestasi Pustaka, 2011.

[10]Lubis, B. O. Penerapan Global Extreme Programming Pada Sistem Informasi Workshop, Seminar Dan Pelatihan Di Lembaga Edukasi. Jurnal Informatika 3(2), 234-246, 2016.

[11]Ferdiana, R. Rekayasa Perangkat Lunak yang Dinamis dengan Global Extreme Programming. Yogyakarta. Andi, 2012.

[12]P. B. A. A. Putra, N. N. K, Sari, E. Christian, Rancang Bangun Aplikasi Mobile Learnig Tenses Bahasa Inggris. Jurnal Teknologi Informasi 13 (2), 37-47, 2017.

[13]V. H. Pranatawijaya. Implementasi Augmented Reality Pada Menu Rumah Makan. Jurnal Teknologi Informasi 14 (1), 21-29, 2020.

[14]P. B. A. A. Putra, V. H. Pranatawijaya, N. N. K. Sari, Implimentasi Location Based Pada Aplikasi Penyajian Ruang Ujian. Jurnal Teknologi Informasi 6 (1), 26-30, 2020.

[15]P. B. A. A, Putra. Implementasi Augmented Reality Pada Media Promosi Penjualan Rumah. Jurnal Teknologi Informasi 11 (1), 58-68, 2017.

[16]P. B. A. A. Putra, N. N. K, Sari, V. H. Pranatawijaya. Analisis dan Desain Website Monitoring Konsultasi Bimbingan Kartu Rencan Studi (KRS). Jurnal Teknologi Informasi 14 (2), 142149, 2020.

[17]P. B. A. A, Putra, V. H. Pranatawijaya, Rancang Bangun Media Pembelajaran Bagi Murid Sekolah Menengah Pertama Luar Biasa (SPMLB) 1 Palangkaraya. Jurnal Teknologi Informasi 18 (1), 79-85, 2018.

[18] V. H. Pranatawijaya. Penerapan Location Based Serviced (LBS) Dalam Prototipe Pengenalan Ruangan Dengan Metode Extreme Programming. Jurnal Teknologi Informasi 15 (1), 92-99, 2021.

[19]V. H. Pranatawijaya. Implementasi Pencatatan Aktivitas Mahasiswa Menggunakan Web Service Pada Feeder PDDIKTI Dengan Metode Extreme Programming. Jurnal Teknologi Informasi 14 (2), 179-188, 2020. 